\title{
Comparative study of midazolam-propofol and metamizole-propofol clinical effects in domestic pigeons")
}

\author{
AMIRABBAS MOUSAVI, GHOLAMREZA ABEDI, \\ ALIREZA JAHANDIDEH, SAEED HESARAKI*
}

Department of Clinical Sciences, *Department of Pathobiology,

Faculty of Specialized Veterinary Sciences, Science and Research Branch, Islamic Azad University, Tehran, Iran

Mousavi A., Abedi G., Jahandideh A., Hesaraki S.

\section{Comparative study of midazolam-propofol and metamizole-propofol clinical effects in domestic pigeons}

\section{Summary}

This study was conducted to determine the quality of anesthesia by evaluating the clinical effects of midazolam-propofol and metamizole-propofol on domestic pigeons (Columba livia). The aim of the study was to choose an appropriate injectable anesthetic protocol by utilizing midazolam and metamizole as pre-anesthetic drugs in order to reduce the dose of propofol and decrease side effects. Eighteen male pigeons weighing 304.2 $\pm 32.3 \mathrm{~g}$ (mean $\pm \mathrm{SD})$ were randomly allocated to three groups of six pigeons each. Midazolam $(6 \mathrm{mg} / \mathrm{kg} / \mathrm{IM})$ and metamizole $(500 \mathrm{mg} / \mathrm{kg} / \mathrm{IM})$ were used five minutes prior to administration of propofol $(8 \mathrm{mg} / \mathrm{kg} / \mathrm{IV})$ in groups I and II, respectively, while the birds in group III (control group) received metamizole (500 mg/kg/IM). Five minutes after the last injection, clinical parameters of various systems were evaluated. Nervous system parameters declined in groups I and II, while reflexes could still be elicited in group III $(\mathrm{P}<0.05)$. There were no significant changes in the heart rate, dysrhythmia, or gastrointestinal parameters in the three groups $(P>0.05)$. The birds in group II showed reduced jaw and limb muscle tone $(P<0.05)$. Corneal and palpebral reflexes were absent in groups I and II $(\mathrm{P}<\mathbf{0 . 0 5})$. Both respiratory depth and pattern were irregular in group I, while all the parameters were normal in group II $(\mathrm{P}<0.05)$. The respiratory rate decreased in all groups after injection, although this reduction was significant only in group I $(P<0.05)$. In conclusion, the combination of metamizole-propofol is safer and more compatible with the physiology of pigeons and can be used for short operations, especially when inhalation agents are contraindicated.

Keywords: anesthesia, metamizole, midazolam, propofol, pigeon

Propofol, 2,6-diisopropylphenol, is a short-acting general anesthetic agent used in animals and humans. It is rapidly metabolized and is administrated intravenously with or without pre-anesthetics. It is also used in the induction of inhalation anesthesia $(17,30)$. It acts by stimulating gamma-aminobutyric acid (GABA) receptors and causes sedative, anesthetic, and analgesic effects $(23,28)$. It has a rapid recovery time and does not accumulate in tissues (18). A number of researchers have reported positive effects of propofol on muscular relaxation and minimum adverse effects on the cardiovascular and respiratory systems, but some other have reported a decreased ventilation rate and respiratory depth and apnea $(9,15)$. Metamizole, methane sulfonic

This study is a part of a dissertation to be submitted by the first author to the Islamic Azad University, Science and Research Branch of Tehran, Iran. The study was supported by the Faculty of Specialized Veterinary Sciences, Science and Research Branch, Islamic Azad University. acid sodium monohydrate or dipyrone, acts rapidly and has analgesic, muscle relaxant, anti-pyretic, and strong anti-inflammatory effects. Its mechanism of action is similar to that of non-steroidal anti-inflammatory drugs (NSAIDs) $(24,29)$. Some studies have shown that inappropriate doses of metamizole could possibly cause hypoxia, dyspnea, peripheral vasodilation, and hypothermia, while appropriate doses may not cause any disorders or renal or hepatic toxicity in the short term $(10,26)$. The side effects of metamizole on the cardiovascular system are not clear, and it has adequate compatibility with the respiratory and renal systems, blood serum, and blood glucose $(2,6)$. Benzodiazepines affect GABA receptors; they have a half-life of one hour in avian species and possess sedative, analgesic, and muscle relaxant effects. However, administration of high doses may induce cardiovascular and respiratory depression and may damage the renal tissue in the 
long term (7). The equipment required for inhalation anesthesia may not be accessible in all clinics, and drug dissemination due to air sac and pneumatic bone damage during surgery is possible, which can threaten both birds and the staff. As a result of the absence of the diaphragm in some birds, gas exchange is completely dependent on the movement of the ribs, sternum, and coracoid bone. The total lung capacity of birds is lower than that of mammals, and they are very sensitive to changes in $\mathrm{CO}_{2}$ concentration. Considering the importance of the cardiovascular system in birds, some inhalation agents sensitize the heart to catecholamine $(16,20,31)$. A rapid recovery time, an appropriate quality of anesthesia, and safety of propofol have been reported for short procedures (11). Its use is approved in intracranial lesions, as it maintains the autoregulation of cerebral blood flow; therefore, it is superior to inhalant agents (5). As the goal in any anesthetic episode in birds is to maintain the lowest possible level of anesthesia taking into account their anatomical and physiological characteristics, the aim of this study was to choose an appropriate injectable anesthetic protocol by utilizing midazolam and metamizole as pre-anesthetic drugs in order to reduce the dose of propofol and decrease side effects.

\section{Material and methods}

Animals, diet, and housing. This study was conducted under the supervision of the ethics committee of the Faculty of Specialized Veterinary Sciences, Science and Research Branch, Islamic Azad University, Tehran, Iran (License no. 5493). Eighteen male pigeons (Columba livia) aged two years and weighing $304.2 \pm 32.3 \mathrm{~g}$ (mean $\pm \mathrm{SD}$ ) were used. Prior to the experiment, the birds were kept in similar conditions and prevented from feeding for four hours and from water consumption for one hour. The birds were controlled for the health status, including the heart rhythm, respiration, and mucous membrane color. An anti-parasite drug was given to all birds. They were then allocated to three groups of six pigeons each.

Drugs. In group I, midazolam $6 \mathrm{mg} / \mathrm{kg}$ was injected intramuscularly as a pre-anesthetic, and propofol $8 \mathrm{mg} / \mathrm{kg}$ was injected intravenously after five minutes. Birds in group II received metamizole $500 \mathrm{mg} / \mathrm{kg}$ intramuscularly followed by propofol injected, as in group I, after five minutes. In group III, or the control group, metamizole $500 \mathrm{mg} / \mathrm{kg}$ was administrated intramuscularly.

Clinical assessment scale. In order to determine anesthetic depth, clinical parameters of the nervous, cardiovascular, gastrointestinal, musculoskeletal, ocular, and respiratory systems were monitored, recorded, and evaluated in all groups five minutes after the last injection according to guidelines for the determination of anesthetic depth in birds (1). The magnitude of the cere and pedal reflexes was measured by pinching and surgical stimulation, which consisted in drilling the tibia with a 1-mm intramedullary pin. Auscultation was used to determine the cardiac rhythm. The heart rate was recorded by a pulse oximeter (A310 fingertip pulse oximeter, Shenzhen Aeon Technology, China) before and 5 minutes after the last injection. The magnitude of all changes in gastrointestinal parameters was recorded by observation. The response rate
Tab. 1. Scoring scale for evaluation of clinical parameters

\begin{tabular}{|c|c|c|c|}
\hline System & Parameters & Evaluation criteria & Score \\
\hline \multirow[t]{4}{*}{ Nervous } & \multirow{4}{*}{$\begin{array}{l}\text { Cere reflex/ } \\
\text { Feather plucking/ } \\
\text { Pedal reflex/ } \\
\text { Surgical stimulation }\end{array}$} & Lack of reflex & 0 \\
\hline & & Mild reflex & 1 \\
\hline & & Moderate reflex & 2 \\
\hline & & Severe reflex & 3 \\
\hline \multirow[t]{4}{*}{ Cardiovascular } & \multirow{4}{*}{$\begin{array}{l}\text { Dysrhythmia } \\
\text { potential }\end{array}$} & No dysrhythmia & 0 \\
\hline & & Mild dysrhythmia & 1 \\
\hline & & Moderate dysrhythmia & 2 \\
\hline & & Severe dysrhythmia & 3 \\
\hline \multirow[t]{4}{*}{ Gastrointestinal } & \multirow{4}{*}{$\begin{array}{l}\text { Reflux potential/ } \\
\text { Salivation/ } \\
\text { Vomiting probability }\end{array}$} & Lack of reflux/salivation & 0 \\
\hline & & Mild & 1 \\
\hline & & Moderate & 2 \\
\hline & & Severe & 3 \\
\hline \multirow[t]{7}{*}{ Musculoskeletal } & \multirow{4}{*}{$\begin{array}{l}\text { Abdominal muscle } \\
\text { tone/Jaw tone/ } \\
\text { Limb muscle tone }\end{array}$} & Atonic & 0 \\
\hline & & Mild muscle tone & 1 \\
\hline & & Moderate muscle tone & 2 \\
\hline & & Severe muscle tone & 3 \\
\hline & \multirow[t]{3}{*}{ Cloacal sphincter } & Atonic & 0 \\
\hline & & Progressive relaxation & 1 \\
\hline & & May void & 2 \\
\hline \multirow[t]{7}{*}{ Ocular } & \multirow{4}{*}{$\begin{array}{l}\text { Corneal reflex/ } \\
\text { Palpebral reflex }\end{array}$} & Lack of reflex & 0 \\
\hline & & Mild reflex & 1 \\
\hline & & Moderate reflex & 2 \\
\hline & & Severe reflex & 3 \\
\hline & \multirow[t]{3}{*}{ Pupil size } & Mydriatic & 0 \\
\hline & & $\begin{array}{l}\text { Variable, often dilated, } \\
\text { may see hippus }\end{array}$ & 1 \\
\hline & & Overdilated & 2 \\
\hline \multirow[t]{15}{*}{ Respiratory } & \multirow[t]{2}{*}{ Cough } & No & 0 \\
\hline & & Yes & 1 \\
\hline & \multirow[t]{4}{*}{ Depth } & Progressive decrease & 0 \\
\hline & & Irregular & 1 \\
\hline & & Irregular or increased & 2 \\
\hline & & Apnea & 3 \\
\hline & \multirow{2}{*}{$\begin{array}{l}\text { Response to } \\
\text { intubation }\end{array}$} & No & 0 \\
\hline & & Yes & 1 \\
\hline & \multirow{3}{*}{$\begin{array}{l}\text { Mucous membrane } \\
\text { and skin color }\end{array}$} & Normal & 0 \\
\hline & & Pale to white & 1 \\
\hline & & Cyanosis & 2 \\
\hline & \multirow[t]{4}{*}{ Pattern } & Normal & 0 \\
\hline & & Occasional breath holding & 1 \\
\hline & & Irregular & 2 \\
\hline & & Apnea \pm Agonal & 3 \\
\hline
\end{tabular}

of musculoskeletal parameters was evaluated by pinching. Loss of corneal and palpebral reflexes was evaluated by touching the peripheral cornea with a dry swab. A penlight was used to assess the pupil size. Changes in the respiratory depth and pattern, cough, and mucose membrane color were determined by observation. Response to intubation was mea- 
sured by inserting an uncuffed endotracheal tube (ID No 2) and determined by observation. The respiratory rate was monitored by observing the chest and abdomen movements prior to anesthesia and five minutes after the last injection. The scoring scale for the evaluation of clinical parameters is presented in Tab. 1.

Statistical analysis. The data were analyzed by the SPSS software (version 22). The Wilcoxon test was used to analyze the heart rate and respiratory rate, while the Kruskal-Wallis test was applied to all other parameters. P values of less than 0.05 were considered significant.

\section{Results and discussion}

All nervous reflexes were present in group III, whereas in groups I and II they were markedly decreased (Tab. 2). According to the intergroup Kruskal-Wallis test, the greatest difference was observed in feather plucking and the pedal reflex $(\mathrm{P}=0.001)$, and the lowest difference was seen in the cere reflex $(\mathrm{P}=0.008)$, as shown in Tab. 3. Intergroup analysis also revealed sig-

Tab. 2. Parameter response changes in all three groups (mean $\pm \mathrm{SD}, \mathrm{n}=18$ )

\begin{tabular}{|l|c|c|c|}
\hline \multicolumn{1}{|c|}{ Parameter/system } & Mid + Pro & Met + Pro & Met \\
\hline Cere reflex & $0.16 \pm 0.816^{\mathrm{c}}$ & $0.33 \pm 1.329^{\mathrm{b}}$ & $2.66 \pm 0.516^{\mathrm{a}}$ \\
Feather plucking & $0.50 \pm 0.547^{\mathrm{c}}$ & $0.83 \pm 0.547^{\mathrm{b}}$ & $2.83 \pm 0.408^{\mathrm{a}}$ \\
\hline Pedal reflex & $0 \pm 0^{\mathrm{c}}$ & $1 \pm 1.095^{\mathrm{b}}$ & $2.83 \pm 0.408^{\mathrm{a}}$ \\
\hline Surgical stimulation & $0.66 \pm 0.516^{\mathrm{c}}$ & $1 \pm 0.516^{\mathrm{b}}$ & $2.33 \pm 0.516^{\mathrm{a}}$ \\
\hline Nervous system & $1.33 \pm 1.378^{\mathrm{c}}$ & $3.16 \pm 2.966^{\mathrm{b}}$ & $10.66 \pm 1.366^{\mathrm{a}}$ \\
\hline Dysrhythmia potential & $1.50 \pm 0.836^{\mathrm{a}}$ & $1.00 \pm 0.632^{\mathrm{a}}$ & $1.16 \pm 0.983^{\mathrm{a}}$ \\
\hline Reflux potential & $0.66 \pm 0.983^{\mathrm{a}}$ & $0.83 \pm 0.752^{\mathrm{a}}$ & $1.50 \pm 1.224^{\mathrm{a}}$ \\
\hline Salivation & $0.66 \pm 0.516^{\mathrm{a}}$ & $0.66 \pm 0.816^{\mathrm{a}}$ & $1.33 \pm 0.516^{\mathrm{a}}$ \\
\hline Vomiting probability & $0.83 \pm 0.752^{\mathrm{a}}$ & $0.83 \pm 0.752^{\mathrm{a}}$ & $0.83 \pm 0.752^{\mathrm{a}}$ \\
\hline Gastrointestinal system & $2.16 \pm 1.366^{\mathrm{a}}$ & $2.33 \pm 0.816^{\mathrm{a}}$ & $3.66 \pm 0.516^{\mathrm{a}}$ \\
\hline Abdominal muscle tone & $1.50 \pm 0.547^{\mathrm{a}}$ & $1.33 \pm 0.516^{\mathrm{a}}$ & $2.00 \pm 0.894^{\mathrm{a}}$ \\
\hline Jaw tone & $1.66 \pm 0.516^{\mathrm{b}}$ & $0.33 \pm 0.516^{\mathrm{c}}$ & $2.16 \pm 0.752^{\mathrm{a}}$ \\
\hline Limb muscle tone & $1.33 \pm 0.816^{\mathrm{b}}$ & $1.00 \pm 0.894^{\mathrm{c}}$ & $2.50 \pm 0.547^{\mathrm{a}}$ \\
\hline Cloacal sphincter & $1.50 \pm 1.048^{\mathrm{a}}$ & $0.66 \pm 0.516^{\mathrm{a}}$ & $2.00 \pm 0.894^{\mathrm{a}}$ \\
\hline Musculoskeletal system & $6.10 \pm 1.264^{\mathrm{b}}$ & $3.33 \pm 1.366^{\mathrm{c}}$ & $8.66 \pm 2.33^{\mathrm{a}}$ \\
\hline Corneal reflex & $0.66 \pm 0.516^{\mathrm{c}}$ & $0.83 \pm 0.752^{\mathrm{b}}$ & $2.66 \pm 0.516^{\mathrm{a}}$ \\
\hline Palpebral reflex & $0.66 \pm 0.516^{\mathrm{b}}$ & $0.66 \pm 0.516^{\mathrm{b}}$ & $2.50 \pm 0.547^{\mathrm{a}}$ \\
\hline Pupil size & $0.66 \pm 0.516^{\mathrm{a}}$ & $0.66 \pm 0.516^{\mathrm{c}}$ & $1 \pm 0.632^{\mathrm{b}}$ \\
\hline Ocular system & $0 \pm 0^{\mathrm{a}}$ & $0 \pm 0^{\mathrm{a}}$ & $0 \pm 0^{\mathrm{a}}$ \\
\hline Cough & $0 \pm 0^{\mathrm{a}}$ & $0 \pm 0^{\mathrm{a}}$ & $0 \pm 0^{\mathrm{a}}$ \\
\hline Depth & $1.16 \pm 0^{\mathrm{a}}$ & $0 \pm 0^{\mathrm{a}}$ & $0.50 \pm 0.547^{\mathrm{b}}$ \\
\hline Mucubation & $2.83 \pm 0.516^{\mathrm{a}}$ & $0.66 \pm 0.516^{\mathrm{c}}$ & $1.50 \pm 0.836^{\mathrm{b}}$ \\
\hline Pattern & $0.816^{\mathrm{c}}$ & $1.50 \pm 1.048^{\mathrm{b}}$ & $5.16 \pm 0.983^{\mathrm{a}}$ \\
\hline Respiratory system & $0.0^{\mathrm{a}}$ & $0 \pm 0^{\mathrm{a}}$ & $0 \pm 0^{\mathrm{a}}$ \\
\hline
\end{tabular}

Explanations: Mid - midazolam; Pro - propofol; Met - metamizole. Clinical parameter responses were scored five minutes after the last injection according to guidelines for the assessment of anesthetic depth in birds. a, b, c-values in the same row with different superscript letters are significantly different $(\mathrm{P}<0.05)$
Tab. 3. The results of Kruskal-Wallis test for all parameters

\begin{tabular}{|c|c|c|c|c|c|c|}
\hline Parameters & Group & N & Mean Rank & Chi-Square & df & Sig. \\
\hline Cere reflex & $\begin{array}{l}\text { I } \\
\text { II } \\
\text { III }\end{array}$ & $\begin{array}{l}6 \\
6 \\
6\end{array}$ & $\begin{array}{c}5.58 \\
8.58 \\
14.33\end{array}$ & 9.546 & 2 & $0.008^{*}$ \\
\hline $\begin{array}{l}\text { Feather } \\
\text { plucking }\end{array}$ & $\begin{array}{l}\text { I } \\
\text { II } \\
\text { III }\end{array}$ & $\begin{array}{l}6 \\
6 \\
6\end{array}$ & $\begin{array}{c}4.25 \\
9 \\
15.25\end{array}$ & 13.798 & 2 & $0.001^{*}$ \\
\hline Pedal reflex & $\begin{array}{l}\text { I } \\
\text { II } \\
\text { III }\end{array}$ & $\begin{array}{l}6 \\
6 \\
6\end{array}$ & $\begin{array}{c}5 \\
8.25 \\
15.25\end{array}$ & 13.668 & 2 & $0.001^{*}$ \\
\hline $\begin{array}{l}\text { Surgical } \\
\text { stimulation }\end{array}$ & $\begin{array}{l}\text { I } \\
\text { II } \\
\text { III }\end{array}$ & $\begin{array}{l}6 \\
6 \\
6\end{array}$ & $\begin{array}{c}4.83 \\
8.83 \\
14.83\end{array}$ & 12.189 & 2 & $0.002 *$ \\
\hline $\begin{array}{l}\text { Dysrhythmia } \\
\text { potential }\end{array}$ & $\begin{array}{l}\text { I } \\
\text { II } \\
\text { III }\end{array}$ & $\begin{array}{l}6 \\
6 \\
6\end{array}$ & $\begin{array}{c}11.33 \\
7.83 \\
9.33\end{array}$ & 1.498 & 2 & 0.473 \\
\hline $\begin{array}{l}\text { Reflux } \\
\text { potential }\end{array}$ & $\begin{array}{l}\text { I } \\
\text { II } \\
\text { III }\end{array}$ & $\begin{array}{l}6 \\
6 \\
6\end{array}$ & $\begin{array}{c}7.83 \\
9.50 \\
11.17\end{array}$ & 1.306 & 2 & 0.521 \\
\hline Salivation & $\begin{array}{l}\text { I } \\
\text { II } \\
\text { III }\end{array}$ & $\begin{array}{l}6 \\
6 \\
6\end{array}$ & $\begin{array}{c}8 \\
7.83 \\
12.67\end{array}$ & 3.938 & 2 & 0.140 \\
\hline $\begin{array}{l}\text { Vomiting } \\
\text { probability }\end{array}$ & $\begin{array}{l}\text { I } \\
\text { II } \\
\text { III }\end{array}$ & $\begin{array}{l}6 \\
6 \\
6\end{array}$ & $\begin{array}{l}9.50 \\
9.50 \\
9.50\end{array}$ & 0 & 2 & 1 \\
\hline $\begin{array}{l}\text { Abdominal } \\
\text { muscle tone }\end{array}$ & $\begin{array}{l}\text { I } \\
\text { II } \\
\text { III }\end{array}$ & $\begin{array}{l}6 \\
6 \\
6\end{array}$ & $\begin{array}{c}9 \\
7.67 \\
11.83\end{array}$ & 2.332 & 2 & 0.312 \\
\hline Jaw tone & $\begin{array}{l}\text { I } \\
\text { II } \\
\text { III }\end{array}$ & $\begin{array}{l}6 \\
6 \\
6\end{array}$ & $\begin{array}{c}11 \\
4 \\
13.50\end{array}$ & 11.218 & 2 & $0.004^{*}$ \\
\hline $\begin{array}{l}\text { Limb muscle } \\
\text { tone }\end{array}$ & $\begin{array}{l}\text { I } \\
\text { II } \\
\text { III }\end{array}$ & $\begin{array}{l}6 \\
6 \\
6\end{array}$ & $\begin{array}{c}7.92 \\
6.33 \\
14.25\end{array}$ & 8.258 & 2 & 0.016 * \\
\hline $\begin{array}{l}\text { Cloacal } \\
\text { sphincter }\end{array}$ & $\begin{array}{l}\text { I } \\
\text { II } \\
\text { III }\end{array}$ & $\begin{array}{l}6 \\
6 \\
6 \\
\end{array}$ & $\begin{array}{c}10.17 \\
5.67 \\
12.67\end{array}$ & 5.922 & 2 & 0.052 \\
\hline $\begin{array}{l}\text { Corneal } \\
\text { reflex }\end{array}$ & $\begin{array}{l}\text { I } \\
\text { II } \\
\text { III }\end{array}$ & $\begin{array}{l}6 \\
6 \\
6\end{array}$ & $\begin{array}{c}6.17 \\
7 \\
15.33\end{array}$ & 11.792 & 2 & $0.003^{*}$ \\
\hline $\begin{array}{l}\text { Palpebral } \\
\text { reflex }\end{array}$ & $\begin{array}{l}\text { I } \\
\text { II } \\
\text { III }\end{array}$ & $\begin{array}{l}6 \\
6 \\
6\end{array}$ & $\begin{array}{c}6.50 \\
6.50 \\
15.50\end{array}$ & 12.706 & 2 & $0.002^{*}$ \\
\hline Pupil size & $\begin{array}{l}\text { I } \\
\text { II } \\
\text { III }\end{array}$ & $\begin{array}{l}6 \\
6 \\
6\end{array}$ & $\begin{array}{l}9.50 \\
9.50 \\
9.50\end{array}$ & 0 & 2 & 1 \\
\hline Cough & $\begin{array}{l}\text { I } \\
\text { II } \\
\text { III }\end{array}$ & $\begin{array}{l}6 \\
6 \\
6\end{array}$ & $\begin{array}{l}9.50 \\
9.50 \\
9.50\end{array}$ & 0 & 2 & 1 \\
\hline Depth & $\begin{array}{l}\text { I } \\
\text { II } \\
\text { III }\end{array}$ & $\begin{array}{l}6 \\
6 \\
6\end{array}$ & $\begin{array}{c}13.50 \\
6.33 \\
8.67\end{array}$ & 2.579 & 2 & 0.030 * \\
\hline Intubation & $\begin{array}{l}\text { I } \\
\text { II } \\
\text { III }\end{array}$ & $\begin{array}{l}6 \\
6 \\
6\end{array}$ & $\begin{array}{l}9.50 \\
9.50 \\
9.50\end{array}$ & 0 & 2 & 1 \\
\hline $\begin{array}{l}\text { Mucous } \\
\text { membrane }\end{array}$ & $\begin{array}{c}\text { I } \\
\text { II } \\
\text { III }\end{array}$ & $\begin{array}{l}6 \\
6 \\
6\end{array}$ & $\begin{array}{l}9.50 \\
9.50 \\
9.50\end{array}$ & 0 & 2 & 1 \\
\hline Pattern & $\begin{array}{l}\text { I } \\
\text { II } \\
\text { III }\end{array}$ & $\begin{array}{l}6 \\
6 \\
6\end{array}$ & $\begin{array}{c}14 \\
5 \\
9.50\end{array}$ & 8.390 & 2 & $0.003^{*}$ \\
\hline
\end{tabular}

Explanations: group I - midazolam-propofol, group II - metamizole-propofol, group III - metamizole. * Significant difference if $\mathrm{P}<0.05$ 
nificant differences between the three groups $(\mathrm{P}=0.001)$ (Tab. 4). Although more dysrhythmia was recorded in group I, the results showed no significant changes in the three groups $(\mathrm{P}>0.05)$, as shown in Tab. 2. The heart rate decreased 5 minutes after the last injection in all groups, and the smallest change was observed in group II (Tab. 5), but these changes were not significant in any of the groups $(\mathrm{P}>0.05)$ (Tab. 6). Although all reflex responses of the gastrointestinal system were more prominent in group III, the results revealed no significant differences between the groups $(\mathrm{P}>0.05)$ (Tab. 3). In addition, the intergroup Kruskal-Wallis test also showed no significant differences $(\mathrm{P}=0.061)(\mathrm{Tab} .4)$. No significant difference was found in the results of cloacal sphincter tone examination $(\mathrm{P}>0.05)$. The muscle tone decreased markedly in group II (Tab. 2); the results of the Kruskal-Wallis test showed significant differences in jaw tone and limb muscle tone between the three groups $(\mathrm{P}=0.004$ and $\mathrm{P}=0.016$, respectively), indicating greater muscle relaxation with metamizole and propofol as compared to the other protocols (Tab. 3). Intergroup analysis showed a significant difference between the three groups $(\mathrm{P}=0.003)(\mathrm{Tab} .4)$. Despite the presence of corneal and palpebral reflexes in group III, they were significantly decreased during anesthesia (Tab. 3) and almost diminished absent in groups I and II (Tab. 2) $(\mathrm{P}<0.05)$. The intergroup Kruskal-Wallis test showed a significant difference between the three groups $(\mathrm{P}=0.003)$ (Tab. 4). The pupil size did not change significantly in any of the groups $(\mathrm{P}>0.05)$. Regarding the respiratory system, cough and response to intubation were not observed in any of the birds; moreover, the mucous membrane was normal during anesthesia (Tab. 2). The results indicated a significantly greater respiratory depth in group I. Depth irregularities were observed in groups I and III. The respiratory pattern was normal in the metamizole-propofol group, but irregular in the midazolam-propofol group (Tab. 2). According to the results of the Kruskal-Wallis test, there were significant differences in the respiratory depth and pattern between the three groups $(\mathrm{P}=0.030$ and $\mathrm{P}=0.003$, respectively) (Tab. 3). The intergroup analysis also showed a significant difference between all groups $(\mathrm{P}=0.003)$ (Tab. 4). The respiratory rate declined $5 \mathrm{~min}-$ utes after the last injection in all the groups (Tab. 5), while the results of the Wilcoxon test indicated a significant change in group I $(\mathrm{P}=0.027)$ (Tab. 6).

Inhalation and injection protocols are used in avian anesthesia. Inhalation agents may not be operational in some clinical situations, such as the surgery of the beak, oropharynx, or tracheal resection $(5,11,15)$. Propofol is administrated as an anesthetic, analgesic, and sedative in humans $(17,30)$, animals $(23,28)$, and various avian species $(21,22)$. Previous studies have recommended the use of pre-anesthetics along with propofol in order to reduce the dose and, more importantly, the side effects $(25,33)$. The main objective of this study was to choose a suitable anesthetic protocol in birds.
Tab. 4. The results of Kruskal-Wallis test for intergroup comparison of all systems

\begin{tabular}{|l|c|c|c|c|c|c|}
\hline \multicolumn{1}{|c|}{ System } & Group & N & Mean Rank & Chi-Square & df & Sig. \\
\hline \multirow{3}{*}{ Nervous } & I & 6 & 4.17 & & & \\
& II & 6 & 8.83 & 13.832 & 2 & $0.001^{*}$ \\
& III & 6 & 15.50 & & & \\
Cardiovascular & I & 6 & 11.33 & & & \\
& II & 6 & 7.83 & 1.498 & 2 & 0.473 \\
& III & 6 & 9.33 & & & \\
Gastrointestinal & I & 6 & 7.25 & & & \\
& II & 6 & 7.75 & 5.599 & 2 & 0.061 \\
Musculoskeletal & III & 6 & 13.50 & & & \\
& I & 6 & 9.75 & & & \\
& III & 6 & 4.17 & 11.646 & 2 & $0.003^{*}$ \\
Ocular & I & 6 & 6.25 & & & \\
& II & 6 & 6.75 & 11.834 & 2 & $0.003^{*}$ \\
Respiratory & III & 6 & 15.50 & & & \\
& I & 6 & 14.67 & & & \\
& II & 6 & 4.83 & 11.557 & 2 & $0.003^{*}$ \\
\hline
\end{tabular}

Explanations: as in Tab. 3

Tab. 5. Heart and respiratory rate results $($ mean $\pm S D, n=18)$

\begin{tabular}{|l|c|c|c|}
\hline \multicolumn{1}{|c|}{$\begin{array}{c}\text { Clinical } \\
\text { parameter }\end{array}$} & Group & Before & After \\
\hline $\begin{array}{l}\text { Heart rate } \\
\text { (beat/min) }\end{array}$ & I & $172.66 \pm 18.02^{\mathrm{a}}$ & $168.50 \pm 15.75^{\mathrm{a}}$ \\
& III & $179.16 \pm 21.74^{\mathrm{a}}$ & $176.16 \pm 20.43^{\mathrm{a}}$ \\
$\begin{array}{l}\text { Respiratory rate } \\
\text { (breath/min) }\end{array}$ & I & $33.16 \pm 3.311^{\mathrm{a}}$ & $23.50 \pm 5.612^{\mathrm{b}}$ \\
& III & $33.66 \pm 3.011^{\mathrm{a}}$ & $30.66 \pm 5.046^{\mathrm{a}}$ \\
\hline
\end{tabular}

Explanations: group I - midazolam and propofol; group II - metamizole and propofol; group III - metamizole. Before - awake status; After -5 minutes after the last injection; $a, b$ - values in the same row with different superscript letters are significantly different $(\mathrm{P}<0.05)$

Tab. 6. Wilcoxon test results for heart and respiratory rates

\begin{tabular}{|c|c|c|c|c|c|}
\hline Parameter & Group & Before/After & Mean Rank & Chi-Square & Sig. \\
\hline \multirow{3}{*}{ Heart rate } & I & $\begin{array}{l}\text { Before } \\
\text { After }\end{array}$ & $\begin{array}{c}3.80 \\
2\end{array}$ & -1.782 & 0.075 \\
\hline & II & $\begin{array}{l}\text { Before } \\
\text { After }\end{array}$ & $\begin{array}{l}3.33 \\
2.50\end{array}$ & -0.674 & 0.500 \\
\hline & III & $\begin{array}{l}\text { Before } \\
\text { After }\end{array}$ & $\begin{array}{c}3.50 \\
1\end{array}$ & -1.761 & 0.078 \\
\hline \multirow{3}{*}{$\begin{array}{l}\text { Respiratory } \\
\text { rate }\end{array}$} & I & $\begin{array}{l}\text { Before } \\
\text { After }\end{array}$ & $\begin{array}{c}3.50 \\
0\end{array}$ & -2.207 & $0.027^{*}$ \\
\hline & II & $\begin{array}{l}\text { Before } \\
\text { After }\end{array}$ & $\begin{array}{c}4.25 \\
2\end{array}$ & -1.378 & 0.168 \\
\hline & III & $\begin{array}{l}\text { Before } \\
\text { After }\end{array}$ & $\begin{array}{c}3.25 \\
2\end{array}$ & -1.511 & 0.113 \\
\hline
\end{tabular}

Explanations: group I - midazolam-propofol; group II - metamizole-propofol; group III - metamizole. Before - awake status; After -5 minutes after the last injection. * Significant difference if $\mathrm{P}<0.05$ 
Therefore, to achieve an appropriate anesthesia depth and muscle relaxation, to decrease side effects, and to increase the safety level, the dose of propofol was reduced. Metamizole and midazolam were used as preanesthetic drugs in groups I and II, respectively, and their clinical effects were compared. Metamizole is used as a pre-anesthetic in various animals $(4,13)$, and a few studies are also available on its use in birds $(2,8)$. In the present study, nervous reflexes differed significantly between the three groups, and the greatest reduction was observed in the midazolam-propofol group, which indicates that anesthetic depth was increased more than expected. Thus, the quality of recovery is smoother with metamizole and propofol. Some researchers have reported a rapid induction and complete recovery in the musculoskeletal system with propofol in quails (19). The results of another study showed that smooth and desirable induction and recovery could be achieved by propofol $(11,18)$. Another study compared the effect of metamizole-propofol and fentanyl-propofol on pedal and pinch reflexes in rabbits. The results showed that metamizole-propofol had better analgesic and anesthetic effects (4). The results of another study showed that metamizole not only induces suitable pharmacological effects, but can also be an alternative to diclofenac sodium in analgesia (2). Evaluation of dysrhythmia showed that metamizole-propofol could have desirable effects on the heart rhythm. The heart rate was reduced insignificantly during anesthesia in all groups. As these changes could not affect the cardiovascular function, it can be concluded that metamizole-propofol is safer for this system. A previous study reported that propofol had minimal effects on the cardiovascular system, although systolic and diastolic pressures decreased insignificantly (27). In another study, no significant difference in the heart rate was observed in parrots anesthetized with propofol (12). Metamizole, as a non-opioid drug, along with propofol has better analgesic results, compared with those of fentanyl (3). Propofol can be considered superior to inhalant agents in intracranial lesions, as it maintains the autoregulation of cerebral blood flow (5). None of the drugs had severe side effects on the gastrointestinal system. Another recent investigation also reports positive effects of metamizole and its safety for the gastrointestinal system (32). The results of the present study demonstrate that metamizole-propofol has better effects on muscle relaxation and reflexes. The results of another study showed that propofol had a rapid induction and good muscle relaxation properties (9). In addition, a complete recovery of the musculoskeletal system was achieved with this agent (14). Both drug combinations in groups I and II almost inhibited corneal and palpebral reflexes, but midazolam with propofol were more potent. The respiratory depth was greater and the respiratory pattern was irregular with midazolam-propofol, whereas with metamizole-propofol, the respiratory depth was appropriate and the pattern was normal. The respiratory rate decreased during anesthesia, and these changes in the midazolam-propofol group were significant, so metamizole-propofol is safer for the respiratory system. Our findings are consistent with the results of studies showing favorable effects of metamizole and propofol on the respiratory system $(8,27)$. Normal levels of $\mathrm{CO}_{2}$ and $\mathrm{O}_{2}$ concentration in the arterial blood were also reported in owls anesthetized with propofol (15). It is also worth noting that the saturation of peripheral oxygen $\left(\mathrm{SpO}_{2}\right)$ and post apneic end-tidal carbon dioxide pressure $\left(\mathrm{PETCO}_{2}\right)$ are not affected by the administration of metamizole and propofol (3).

The present study shows that a combination of metamizole and propofol is safer and has favorable effects, especially on the musculoskeletal and respiratory systems. Upon clinical evaluation, this combination could be used as a reliable anesthetic protocol for short operations in pigeons, especially when inhalation agents are contraindicated.

\section{References}

1.Altman B., Clubb L., Dorrestein M., Quesenberry K.: Avian Medicine and Surgery, Saunders, St. Louis. 1997, pp. 818

2. Asif Farooq A., Muhammad A., Owais U., Taha N., Muhammad S., Habib U.: Studies of metamizole sodium toxicity in avian species. J. Appl. Pharmac. Sci. 2009, 1, 1-6.

3. Baumgartner C. M., Koenighaus H., Ebner J. K., Henke J., Schuster T., Erhardt $W$. D.: Cardiovascular effects of dipyrone and propofol on hemodynamic function in rabbits. American J. Vet. Res. 2009, 70, 1407-1415.

4. Baumgartner C. M., Koenighaus H., Ebner J. K., Henke J., Schuster T., Erhardt $W$. D.: Comparison of dipyrone/propofol versus fentanyl/propofol anesthesia during surgery in rabbits. Lab. Animals. 2011, 45, 38-44.

5. Bigby S. E., Carter J. E., Bauquier S., Beths T.: Use of propofol for induction and maintenance of anesthesia in a king penguin (Aptenodytes patagonicus) undergoing magnetic resonance imaging. J. Avian Med. Surgery 2016, 30, 237-242.

6. Canory W.: The European Agency for the Evaluation of Medicine Products. Vet. Med. Inspection. 2003, 2, 1-10.

7. Churchill L.: Metabolism of benzodiazepines in rats. J. Vet. Med. 2000, 3, 51-52.

8. Lotfi F., Abedi Gh., Asghari A., Sheykhi N., Hesaraki S.: Study of the histopathological effects of metamizole as a premedication in pigeons. Internat. $\mathrm{J}$ Biol. Pharm. Allied Sci. 2015, 4, 5860-5873.

9. Fitzgerald G., Cooper J. E.: Preliminary studies on the use of propofol in the domestic pigeon (Columba Livia). Res. Vet. Sci. 1990, 49, 334-338.

10. Fowler J. D., Bauck L., Crib P. H.: Surgical correction of tibiotarsal rotation in an emu. Comp. Anim. Pract. 1987, 1, 26-30.

11. Gary R., Chad A.: A comparison of methoxyflurane and propofol to reduce nest abandonment by wood ducks. Wildlife Soc. Bull. 2001, 29, 546-550.

12. Isabelle L., Ralph C., Michael P., Juergen S.: Cardiopulmonary and anesthetic effects of isoflurane and propofol in Hispaniolan Amazon parrots (Amazona ventralis). J. Avian Med. Surg. 2003, 17, 4-10.

13. Jedziniak P., Pietruk K., Olejnik M.: Rapid method for the determination of metamizole residues in bovine muscle by LC-MS/MS. J. Vet. Anesth. Analg. 2013, 30, 977-982

14. Kembro J. M., Guzman D. A., Perillo M. A., Marin R. H.: Temporal pattern of locomotor activity recuperation after administration of propofol in Japaness quail (Coturnix coturnix japonica). Res. Vet. Sci. 2012, 93, 156-162.

15. Khursheed R., Lyndsay G., Peter J.: Use of propofol for induction and maintenance of anesthesia in a barn owl (Tyto alba) undergoing tracheal resection. J. Zoo Wildl. Med. 1996, 27, 397-401.

16. Lesa L.: Avian anesthesia, [in:] Anesthesia of Exotic Pets, Lesa Longley, Saunders Ltd., London 2008, pp. 129-176.

17. Lundström S., Twycross R., Mihalyo M., Wilcock A.: Therapeutic reviews: propofol. J. Pain Symptom Manag. 2010, 40, 466-470.

18. Naser A., Mohammad F.: Central depressant effects and toxicity of propofol in chicks. Toxicol. Rep. 2014, 1, 562-568. 
19. Machin K. L., Caulkett N. A.: Evaluation of isoflurane and propofol anesthesia for intra-abdominal transmitter placement in nesting female canvasback duck. J. Wildlife Dis. 2000, 36, 324-334.

20. Mclelland J.: Anatomy of the lungs and air sacs, [in:] King A. S., McLelland J. (eds): Form and function in birds. Academic Press, London 1989, p. 221-279.

21. Mulcahy D. M., Gartrel L. B., Gill R. E., Tibbitts T. L., Ruthrauff D. R.: Coelomic implantation of satellite transmitters in the bar-tailed godwit (Limosa lapponica) and the bristle-thighed curlew (Numenius tahitiensis) using propofol, bupivacaine, and lidocaine. J. Zoo Wildl. Med. 2011, 42, 54-64.

22. Muller K., Holzapfel J., Burnnberg L.: Total intravenous anesthesia by boluses or by continuous rate infusion of propofol in mute swans (Cygnus olor). Vet. Anesth. Analg. 2011, 34, 286-291.

23. Papich M. G., Chapter P.: [in:] Saunders Handbook of Veterinary Drugs. St. Louis: Elsevier-Saunders, MO 2011, p. 658-660.

24. Poblete B., Romand A., Koning P.: Metabolic effect of i.v. propacetamol, metamizol or external cooling in erotically ill febrile sedated patients. J. Vet. Anesth. Analg. 2003, 10, 78-123.

25. Priyesh B., Anita M., Rajni K., Monica K.: Effects of midazolam premedication on the dose of propofol for laryngeal mask airway insertion in children. Journal of Anaesthesiology Clinical Pharmacol. 2010, 26, 503-506.

26. Samour J. H., Jones D. M., Knight J. A.: Comparative study of the use of some injectable anesthetic agents in birds. Vet. Rec. 1984, 115, 6-11.
27. Schumacher J., Citino S. B., Hernandez K., Hutt J., Dixon B.: Cardiopulmonary and anesthetic effects of propofol in wild turkeys. Am. J. Vet. Res. 1997, 58, 1014-1017.

28. Short C. E., Bufalari A.: Propofol anesthesia. Vet. Clin. North America: Small Anim. Prac. 1999, 29, 747-778.

29. Sinn L. C.: Anesthesiology, [in:] Zantop D. W. (ed.): Avian medicine: principles and application. Wingers Publishing, Inc., Lake Worth, FL 1997, p. 589-599.

30. Smith I., White P. F., Nathanson M.: Propofol: an update on its clinical use. Anesthesiology 1994, 81, 1005-1043.

31. Sturkie P. D.: Heart and circulation: blood pressure, blood flow, [in:] Sturkie P. D., Paul D. (eds): Avian physiology. Springer Verlag, New York 1986, p. $130-166$.

32. Vinagre M. A.: The effect of dipyrone on liquid gastric emptying. J. Vet. Anesth. Analg. 2012, 4, 50-52.

33. Wilder-Smith O. H., Ravussin P. A., Decosterd L. A., Despland P. A., Bissonnette $B .:$ Midazolam premedication reduces propofol dose requirements for multiple anesthetic endpoints. Canad. J. Anesthesia 2001, 48, 439-445.

Corresponding author: Dr. Gholamreza Abedi, Science and Research Branch, Daneshgah Blvd, Simon Bulivar Blvd, Tehran, Iran; e-mail: mousavi.vet@gmail.com 